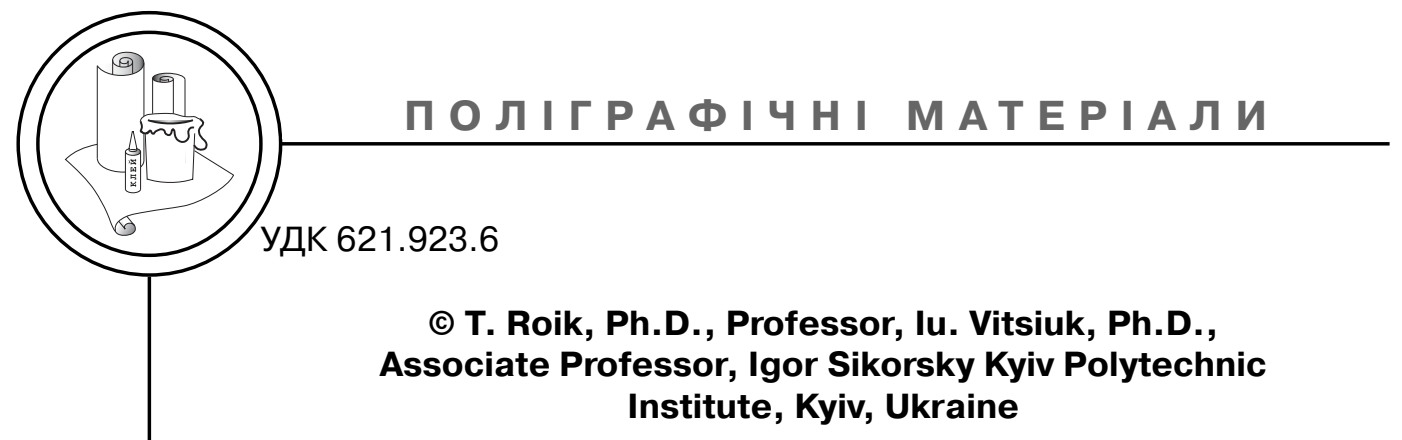

\title{
THE MANUFACTURING TECHNOLOGY AND ITS EFFECT ON THE TRIBOLOGICAL PROPERTIES OF THE NEW PARTS FOR PRINTING MACHINES
}

The article reveals the features of the development of manufacturing technology and its effect on the antifriction properties of the new antifriction parts based on the EP975 nickel alloy composite materials with solid lubricant $\mathrm{CaF}_{2}$, which is intended for high speed printing equipment.

The article summarizes the formation of new materials' structure and antifriction properties after using a new manufacture technology. The results of industrial tests confirmed the efficiency of the developed manufacturing technology for bearings. The results of the new composite material's tribotechnical properties have been presented in a comparison with the already known nickel composite. The industrial tests of the new composite antifriction parts have been carried out in the friction units of the printing machines. The visual inspection and measurement of surface roughness showed that the contact surfaces of bearings are not damaged, have high quality, and are usable. Industrial tests of EP975-CaF2 bearings showed an increase in wearing resistance by a factor of 5-6, compared with the already known antifriction parts.

Keywords: manufacture technology; antifriction parts;
composite materials; printing machines; bearings.

Introduction

The development of a modern technical equipment in the machinebuilding industry has a great importance for the problem of increasing the machines and mechanisms' durability. It is no more an important problem among the tasks of creation the new technical objects. The extension of a useful service period for machines, mechanisms and equipment even in a small measure is equivalent an introduced new production capacities [1, 2].

Questions of the technical evolution were continually connected with the problems of materials' science development. The questions of the new materials' using took a central place in the general problem of machines and equipment quality increase, including materials of contact pairs such as antifriction (bearing) materials. 
Among these bearing materials, which operate with a lubrication at easy operation conditions (low loadings, speeds of sliding, temperature up to $100^{\circ} \mathrm{C}$ ), and especially it is important for the friction units, which operate in extreme conditions - at the high loadings, aggressive environment, increased and high temperatures $200-800^{\circ} \mathrm{C}$, high speeds of rotation up to $10000 \mathrm{rpm}$. Well-known fact $-80 \%$ refuses of machines and mechanisms took place because of destruction friction units' $[1,2]$.

Such phenomens are inherent for the equipment of metallurgical industry, oxygen-converter equipments, waste-smelting aggregates, heating equipment, aggregates and equipment of power engineering industry and high-speed printing equipment.

An action of high speeds, specific loadings and influence of oxidizing atmosphere - here is an incomplete list of aggressive factors, which accompany working of the rotary printing machines' parts, and cause the intensive wear of friction units.

A large assortment of the cast and powder antifriction materials, based on of iron, cast iron, copper and nickel are developed and applied for the listed high-heavy working conditions [1-3]. An intensive wearing and high friction coefficient have connected with an imperfection of manufacturing technologies. Moreover, a high cost unites these materials. And yet cast materials that use in extreme working conditions, such as cast iron, bronze, the non-ferrous alloys are unable to combine different additives in a composi- tion, which would form a strong matrix and contain antiscoring additives, such as sulfides, oxides, chalcogenides and fluorides.

The main task in the development of the new composite bearing materials for printing machines is to increase the life of such equipment by, for example, applying lubricants in order to operate under conditions of high loads, temperatures or the rotation speeds.

Among the antifrictional composite materials intended for severe operating conditions and incorporating solid lubricants, materials, based on copper, iron, nickel, cobalt, and ceramics $\left(\mathrm{Al}_{2} \mathrm{O}_{3} / \mathrm{TiC} /\right.$ $\left.\mathrm{CaF}_{2}, \mathrm{Al}_{2} \mathrm{O}_{3} / \mathrm{CaF}_{2} / \mathrm{AgO} / \mathrm{CaF}_{2}\right)$ are well known [1-4].

The composite materials, based on iron or alloy powder steel are known for using at the speeds of $\mathrm{V}<400 \mathrm{rpm}$ and loads up to 3.0 $\mathrm{MPa}$. At higher speeds ( $\mathrm{V} \geq 600 \mathrm{rpm})$ and loads up to 1.5-5.0 MPa, materials, based on nickel, cobalt and copper are used $[3,4]$. This is due to their original physical properties [1, 2].

The already known powder and cast alloys, based on nickel (or cobalt) demonstrate unsatisfactory tribotechnical properties high friction coefficient and wearing at heavy-duty conditions of printing machines [1, 2].

Therefore, as a basis for bearings materials, a composite nickel alloy there was selected - marked as EP975 for heavy-duty conditions, such as increased loadings, air environment and rotation speeds 8000-10000 rpm. This choice was caused by the complete absence of known alloys' operability both cast and powder, based on copper, iron, nickel at 
such operation conditions. The big number of alloy elements in the nickel matrix (more than 35 mas. \%) gives an alloy EP975 high physical and physical-mechanical properties.

In the conditions of the high rotation speeds any liquid lubricant is disabled because the liquid lubricant was throwed out from the friction zone by the centrifugal forces. It is especially important to protect the friction surfaces from the increased wearing and frictional seizure. The numerous studies show that using solid lubricants as an component of materials improves the tribotechnical characteristics of the plain bearings [3-6]. For example, calcium fluoride $\mathrm{CaF}_{2}$ as a thermal and chemical stable substance is widely used as a solid lubricant to improve frictional contact, especially in heavy-duty conditions $[1,2$, $5,6]$.

These arguments were a reason for complex researches, which are directed for creation of the new bearings materials for the wide range of loadings (3.0-5.0 $\mathrm{MPa}$ ) and rotation speeds by $8000-10000 \mathrm{rpm}$ on the basis of the scientifically grounded material science approach with the purpose to obtain the possibility of prognostics and control of materials functional properties.

Moreover, it is of the theoretical and practical importance to establish an effect of making technology on structure and properties, distribution of $\mathrm{CaF}_{2}$ over the metal matrix, and its effect on the friction behavior of nickel alloy EP975-based materials in extreme operating conditions of printing machines.
The objective of the present paper is to research the bearing nickel alloy EP975-based composite materials with a $\mathrm{CaF}_{2}$ additions for heavy-duty conditions (high rotation speeds and high pressures), to study the formation of the new materials' structure and properties.

\section{Experimental results and discussion}

Examination Techniques. The structure was studied with a using of a metallographic microscopy; calcium fluoride in the matrix was identified by using a scanning electron microscopy (SEM). Moreover, the SEM images were used for the quantitative description of $\mathrm{CaF}_{2}$ in the composite. The physic mechanical properties of the samples were determined as well. Tribological tests were performed on a VMT-1 friction testing machine (rotation speeds $V=8000-10000$ rpm and pressure $\mathrm{P}=3.5 \mathrm{MPa}$ ), the counterface is made of R18 tool steel (HRC = 53-55); shaftpin friction pair.

The chemical composition of EP975 has presented in tab. 1 [7].

In our experiments we researched such compositions as EP975+ (4.0-8.0)\% $\mathrm{CaF}_{2}$.

The powders of the high-alloyed nickel alloy EP975 have been produced by the powder spraying method of metal melted by argon stream. Dispersed metal drops were crystallized as spherical particles with the dimensions from 10 to $750 \mu \mathrm{m}$. Usually, optimum dimensions of fractions are in the range of $37-250 \mu \mathrm{m}$. In our case powders of alloy EP975 there were of $50-250 \mu \mathrm{m}$. Spherical particles of alloy have been represented on fig. 1. 
Chemical composition of EP975

\begin{tabular}{|c|c|c|c|c|c|c|c|c|}
\hline \multicolumn{10}{|c|}{ Chemical elements, mas. \% } \\
\hline $\mathrm{C}$ & $\mathrm{W}$ & $\mathrm{Cr}$ & $\mathrm{Mo}$ & $\mathrm{Ti}$ & $\mathrm{Al}$ & $\mathrm{Nb}$ & $\mathrm{Co}$ & $\mathrm{Ni}$ \\
\hline $0.038-$ & $8.65-$ & $7.6-9.5$ & $2.28-$ & $1.71-$ & $4.75-$ & $1.71-$ & $9.5-$ & \multirow{2}{*}{ basis } \\
0.076 & 9.31 & & 3.04 & 2.09 & 5.13 & 2.59 & 11.4 & \\
\hline
\end{tabular}

The hard spherical powder particles of the high-alloyed nickel alloy EP975 are a real microingot that excludes the problem of liquation at once. This problem is typical for the cast nickel alloys, obtained by traditional technology.

The traditional technology of the powder metallurgy - pressing and sintering of initial mixture $\left(\mathrm{EP} 975+\mathrm{CaF}_{2}\right)$ - is unacceptable in our case, because the minimum porosity is already impermissible.

That is why the method of hot isostatic-pressing (HIP) was used for creation of new materials. The hot isostatic pressing (or gasstatic pressing) is executed on the special presses - gasostat. Hot isostatic pressing is carried out in a liquid (hydrostatical) or gas (gasostatical) environment. A working environment is forced to hermetic chamber by compressors and creates pressure of few thousand atmospheres. The isostatic press- ing can combine high pressure with a high temperature that allows combining the process of forming and sintering.

Thus, first of all - initial components of the sprayed powders of nickel alloy EP975 and solid lubricant (calcium fluoride) are mixed up during 4-6 hours. And then mixed powders are loaded to the special steel containers. The filled containers are pressurized for getting of a vacuum density. The process of hot isostatic pressing was carried out at $1210 \pm 10^{\circ} \mathrm{C}$, during 4 hours, under pressure of argon up to $140 \mathrm{MPa}$.

The equipment for HIP allows obtaining enough dense materials, almost without pores.

The blanks had a relative density $99.9 \%$.

After the hot isostatic pressing a heat treatment was carried out for optimization of dispersible phases' morphology in the structure

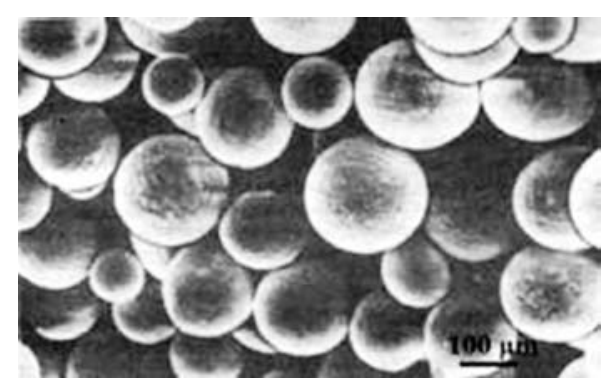

Fig. 1. Spherical particles of EP975 alloy produced by powder spraying in argon, $\times 100$ 
of materials and for obtaining a necessary level of physics-mechanical and antifriction properties.

Heat treatment includes hardening - heat to $1240^{\circ} \mathrm{C}$ during 4 hours, cooling with speed a 40 degrees/hour with a furnace to $1200^{\circ}$ $\mathrm{C}$, and then cooling on air.

After a hardening an ageing was carried out at $910^{\circ} \mathrm{C}$ during 16 hours on air.

A general scheme of the technological operations for manufacture of nickel alloy EP975-based bearing materials is presented on the fig. 2.
The HIP with a next aging is promoted to formation of phases in a structure, which increase the physical mechanical properties of material (combination of the strength and plasticity), and improve operating reliability of a friction part.

A microstructure of composition material EP975+8\% $\mathrm{CaF}_{2}$ after heat treatment is presented on fig. 3.

The structure of material is heterogeneous. There is a metallic matrix with inclusions of solid lubricant $\mathrm{CaF}_{2}$. The solid lubricant $\mathrm{CaF}_{2}$ particles were uniformly arranged.

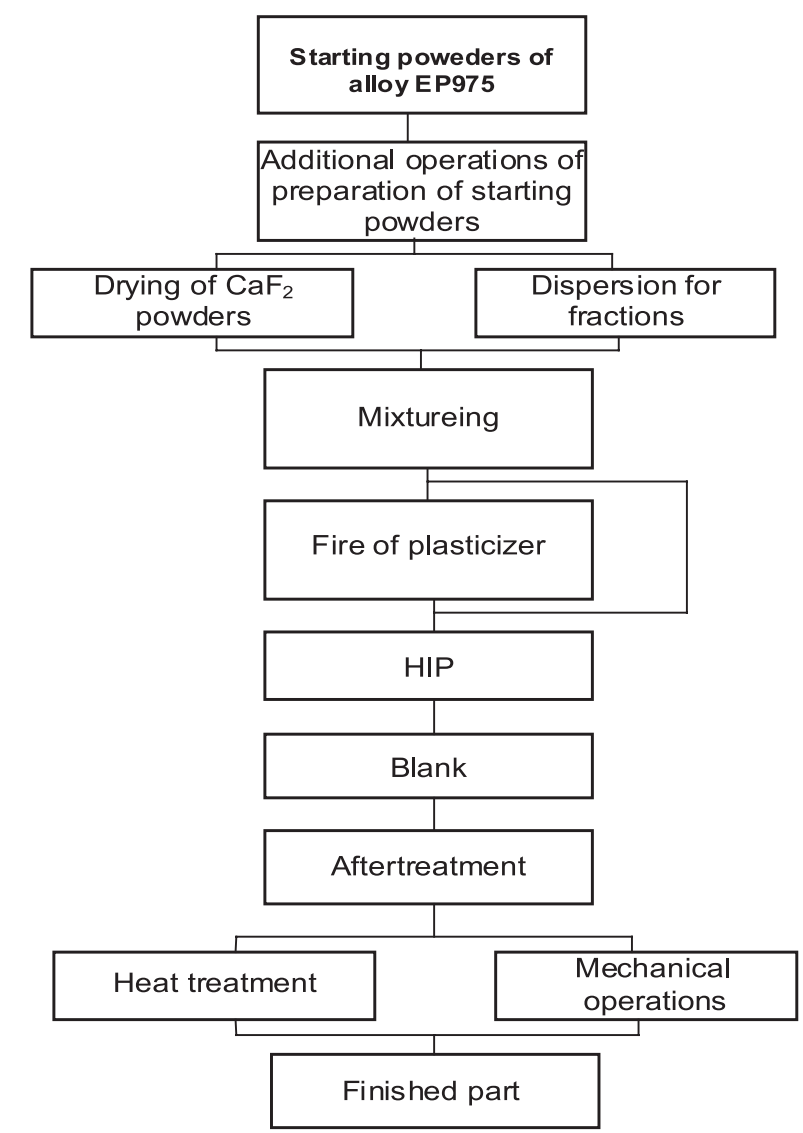

Fig. 2. Technological manufacturing scheme of the composite bearing materials $\mathrm{EP} 975+6 \% \mathrm{CaF}_{2}$ 


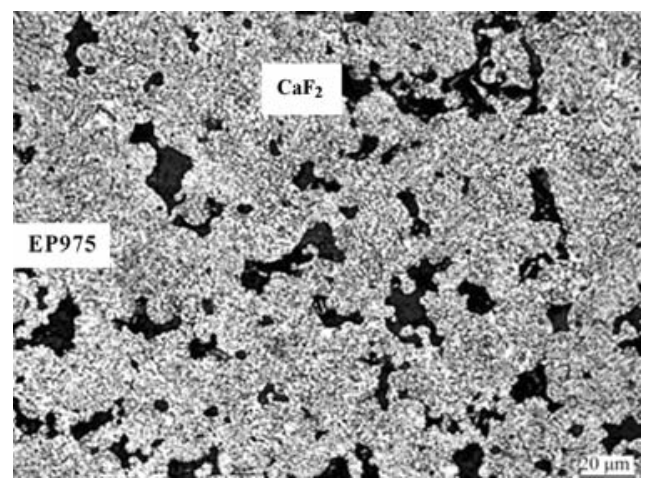

Fig. 3. The microstructure of material EP975+8\% $\mathrm{CaF}_{2}$ after heat treatment, etched specimen

The metallic matrix in the alloyed $\gamma$-solid solution on the nickel basis with particles of alloy metal carbides and intermetallic compounds.

The presence of alloy elements big number in a nickel matrix gives the new materials a high physicalmechanical and tribotechnical properties. Aluminum and titanium, and also tungsten in less degree, molybdenum and niobium make for strengthening of $\mathrm{Ni}$ alloy $[7,8]$ due to strengthening compounds formation.

These elements provide the increase of strength and besides
$\mathrm{Nb}$ grinds down grains strongly. A presence of $\mathrm{Co}$ in an alloy positively influences for plasticity of material especially in a presence of Ti, W, Mo, Al, Cr [1, 2].

Tribotechnical and physicalmechanical properties of new materials have been presented at tab. 2 in a comparison with known Ni-powder material [1,2], which is applied in analogue conditions.

Analyzing on information of tab. 2 evidently new high-speed bearings materials on the basis of EP975 alloy with the addition of $\mathrm{CaF}_{2}$ have higher properties in a comparison with the known mate-

Table 2

Antifriction properties of materials based on alloy EP975

\begin{tabular}{|c|c|c|c|c|c|}
\hline \# & Composition, mas. \% & $\begin{array}{l}\text { Friction } \\
\text { coefficient }\end{array}$ & $\begin{array}{c}\text { Wear, } \mu / \mathrm{km} \\
(\mathrm{V}=8000 \\
\mathrm{rpm})\end{array}$ & $\begin{array}{l}\text { Limit load, } \\
\text { MPa }\end{array}$ & $\begin{array}{l}\text { Limit rotation } \\
\text { speed, rpm }\end{array}$ \\
\hline 1 & EP975+4\%CaF 2 & 0.274 & 65 & 3.5 & 10000 \\
\hline 2 & EP975+6\% $\mathrm{CaF}_{2}$ & 0.267 & 62 & 3.5 & 10000 \\
\hline 3 & $\mathrm{EP} 975+8 \% \mathrm{CaF}_{2}$ & 0.271 & 67 & 3.5 & 10000 \\
\hline 4 & $\begin{array}{c}\mathrm{Ni}+(18-45 \%) \mathrm{MoB}_{2}+ \\
\left.+\mathrm{ZrB}_{2}\right)+5 \%\left(\mathrm{CaF}_{2} \text { or }\right. \\
\left.\mathrm{BaF}_{2}\right) \text { sintered alloy [1] }\end{array}$ & 0.352 & 380 & 1.5 & $1000-1200$ \\
\hline
\end{tabular}


rial $[1,2,8]$, and they are able to operate at higher rotation speeds and loads.

\section{Conclusions}

We have obtained a new effective material in the Ni alloy EP975$\mathrm{CaF}_{2}$ system with high antifrictional properties performing well in more severe conditions than the already known sintered alloy.

The new material owes its high tribotechnical characteristics to the tribofilms formed on the contact surfaces by dragging of calcium fluoride to cover the entire friction area.

The full-scale industrial tests of the new composite bearing mate- rials in friction units of printing machines have been conducted. Fifteen benchmark evaluations of friction units have been made. The visual inspection and measurement of surface roughness showed, that the contact surfaces of bearings are not damaged, have high quality, and are usable.

The full-scale tests of EP975$\mathrm{CaF}_{2}$ bearings showed increase in wearing resistance by a factor of 5-6 compared with the already known bearings. It's connected with using of new making technology. Such technology is able to ensure the high and stable level of functional properties.

\section{References}

1. Roik, T. A. \& Kyrychok, P. O. \& Gavrysh, A. P. (2007). Composite bearing materials for higher operation conditions. Kyiv: NTUU 'KPI' [in Ukrainian].

2. Kyrychok, P. O. \& Roik, T. A. \& Gavrysh, A. P. \& Shevchuk, A. V. \& Vitsuk, lu. lu. (2015). New composite materials of the friction parts for printing machines. Kyiv: NTUU 'KPI' [in Ukrainian].

3. Konopka, K. \& Roik, T. A. \& Gavrysh, A. P. (2012). Effect of $\mathrm{CaF}_{2}$ surface layers on the friction behavior of copper-based composite. Journal of Powder Metallurgy and Metal Ceramics. New York: Springer, Vol. 51, Number 5-6, 363-367 [in English].

4. Roik, T. A. \& Gavrysh, A. P. \& Kyrychok, P. A. \& Vitsiuk, lu. lu. (2015). Effect of secondary structures on the functional properties of high-speed sintered bearings for printing machines. Journal of Powder Metallurgy and Metal Ceramics. New York: Springer. Vol. 54, Issue 1, 119-127 [in English].

5. Julthongpiput, D. \& Ahn, H. S. \& Sidorenko, A. (2001). Towards self-lubricated nanocoatings. Journal of Tribol. Int., 35, 829-836 [in English].

6. Jianxin, D. \& Tongkun, C. (2007). Self-lubricant mechanisms via the in situ formed tribofilm of sintered ceramics with $\mathrm{CaF}_{2}$ additions when sliding against hardened steel. Journal of J. Refract. Met. Hard Mater., 25, No. 2, 189-197 [in English].

7. Roik, T. A. \& Gavrysh, A. P. \& Kyrychok, P. O. Composite Bearing Material // Ukrainian Patent No. 60521, IPC (2009), C22C9/02, Bulletin No. 12, Publ. June 25, 2011.

8. Gavrysh, A. P. \& Kyrychok, P. A. \& Roik, T. A. \& Zorenko, O. V. \& Oliinyk, V. H. (2016). Precision grinding and polishing of printing machines' parts from highalloyed composites. Kyiv: NTUU 'KPI' [in Ukrainian]. 
У статті представлено особливості технології виготовлення та її вплив на антифрикційні властивості нових деталей тертя на основі композиційних матеріалів з нікелевого сплаву ЕП975 із домішками твердої змащувальної речовини $\mathrm{CaF}_{2}$, які призначено для високошвидкісного друкарського обладнання. Узагальнено формування структури і властивостей нових антифрикційних матеріалів після застосування нової

технології виготовлення. Результатами промислових випробувань підтверджено ефективність розробленої технології виготовлення підшипників ковзання. Результати

триботехнічних властивостей нових композиційних матеріалів представлено порівняно з відомим нікелевим композиційним сплавом. Промислові випробування нових композиційних антифрикційних деталей проведено у вузлах тертя друкарських машин. Візуальний огляд і вимірювання шорсткості показали, що контактні поверхні підшипників не пошкоджені, мають високу якість і можуть використовуватися у виробництві. Промислові випробування ЕП975-CaF підшипників ковзання показали збільшення зносостійкості у 5-6 разів порівняно з вже відомими антифрикційними деталями.

Ключові слова: технологія виготовлення; антифрикційні деталі; композиційні матеріали; друкарські машини; підшипники ковзання.

В статье представлены особенности технологии изготовления и ее влияние на антифрикционные свойства новых деталей трения на основе композиционных материалов из никелевого сплава ЕП975 с включениями твердой смазки $\mathrm{CaF}_{2}$, предназначенные для высокоскоростного печатного оборудования. Обобщено формирование структуры и свойств новых антифрикционных материалов после применения новой технологии.

Подтверждена результатами промышленных испытаний эффективность разработанной технологии изготовления подшипников скольжения. Представлены результаты триботехнических свойств новых композиционных материалов по сравнению с уже известным никелевым композиционным сплавом. Промышленные испытания

новых композиционных антифрикционных деталей проведены в узлах трения печатных машин. Визуальный

анализ и измерения шероховатости показали, что контактные поверхности подшипников не повреждены, 
имеют высокое качество и могут применяться в производстве. Промышленные испытания ЕП975-CaF 2

подшипников скольжения показали увеличение износостойкости в 5-6 раз по сравнению с известными антифрикционными деталями.

Ключевые слова: технология изготовления; антифрикционные детали; композиционные материалы; печатные машины; подшипники скольжения.

Рецензент - О. І. Лотоцька, к.т.н., доцент, КПІ ім. Ігоря Сікорського

Надійшла до редакції 17.11.16 